\title{
THE BRITISH SURVEY
}

This monthly deals with world topics and countries of current international interest

Main Series

Recent issues include-

What's wong with NATO-I. M. Lombardo

Are the British Soft?-J. Eppstein (December 1961)

Towards Utopia—Soviet man, fact or fiction-A. Wiseman

The Liberation of Goa (January 1962)

Tanganyilka since Independence (February 1962)

Review of the Year 1961 (March 1962)

Popular Series

Price 1s. 6d.

Hong Kong (January 1962)

Men in Space (February 1962)

Write to:

Price 10d.

The EdTTOR, British Survey,

Benjamin Frankin House,

36 Craven Street, London, W.C.2.

\section{Annomcing the WINTER 1962 Issue of O R B IS}

\section{a Quarterly Journal of World Affairs}

Emesto De Marchl: TRENDS IN ITALY : AN “ OPENING TO THE LEFT?" Herbert $S$. Dinerstein: SOVIET GOALS AND MILITARY FORCE

Milorad M. Drachkovitch: THE EMERGING PATTERN OF YUGOSLAVSOVIET RELATIONS

James $R$. Schlesinger: ECONOMIC GROWTH AND NATIONAL SECURITY

Frederick H. Gareau: BLOC POLITICS IN WEST AFRICA

James E. Dougherty: THE DISARMAMENT DEBATE: A REVIEW OF CURRENT LITERATURE, Part Two

Review articles on important new books th the field of international relations

ORBIS is published four times yearly, in January, April, July and

October. Individual copies: $\$ 1.50$. Yearly subscriptions: $\$ 5.00$.

Address orders to:

The Foreign Policy Research Institute

University of Pennsylvania

133 South 36th Street

Philadelphia 4, Pa. 


\title{
SURVEY
}

A Journal of Soviet and East European Studies

announces the publication of a special issue on THE WESTERN IMAGE OF THE SOVIET UNION

\author{
(ca. 200 pages)
}

a long overdue reappraisal-in the light of recent disclosures-of some of the important books that influenced Western thinking on Russia-from Bertrand Russell's "BOLSHEVISM" to Isaac Deutscher's "STALIN." It includes reassessments of Webb's "SOVIET COMMUNISM: A NEW CIVILISATION," the literature of the "purge," Amerscan writing in the 'thirties, Harold Laskj and G. D. H. Cole, the rolo of the New Statesman, and the later works of Leon Trotsky. It also contains a new short story by Abram Tertz, and an extensive review section on recently published literature on the Soviet Union and Eastern Europo.

\section{SURVEY}

is published every other month.

Yearly subscription rates: $\$ 1$ or $\$ 3.00$; France, $14 \mathrm{NF}$; Germany, $12 \mathrm{DM}$. Special student rates: 10 s. or $\$ 2.00$; elsewhere, half price.

Write for further information and a specimen copy to

\section{SURVEY}

SUMMIT HOUSE, 1 LANGHAM PLACE, LONDON, W.1.

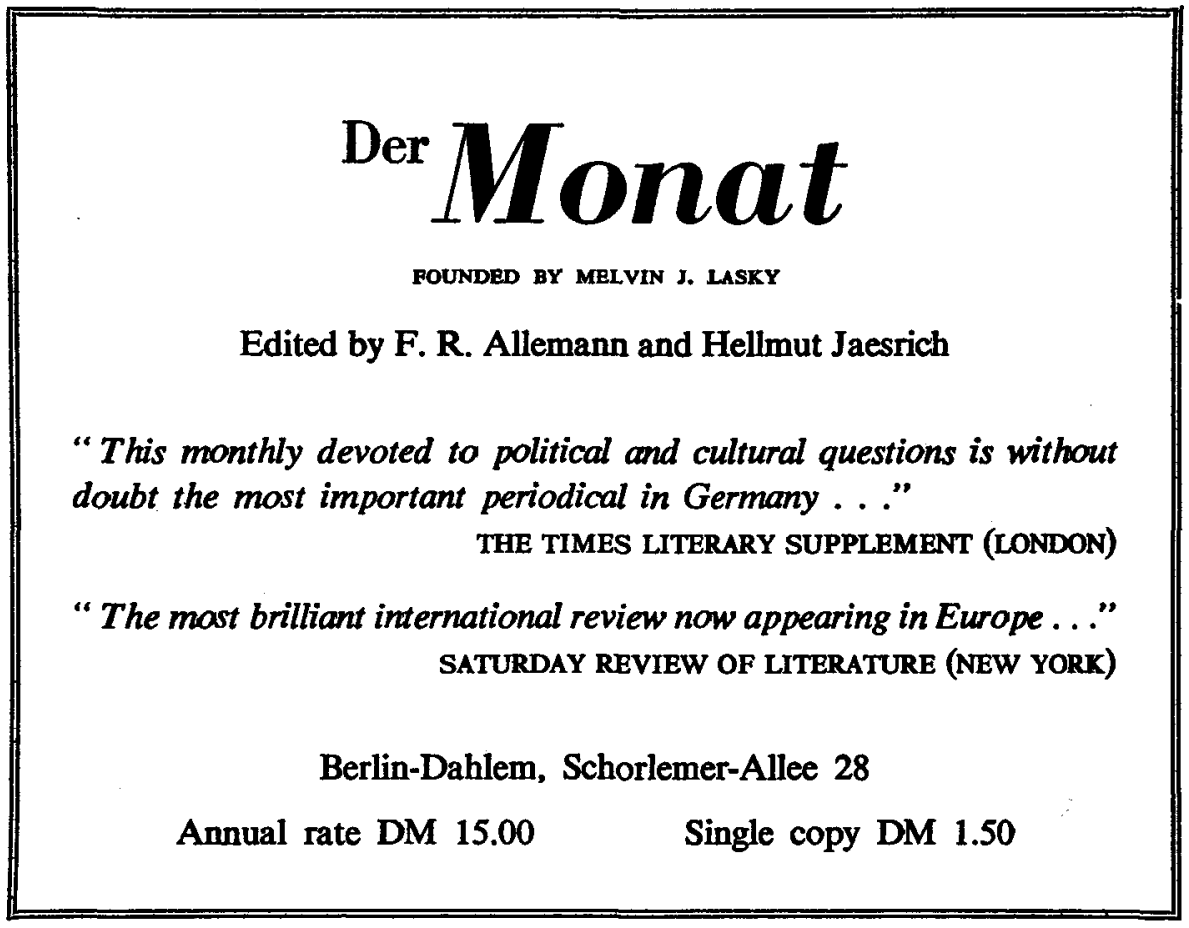




\section{COMPARATIVE STUDIES IN SOCIETY AND HISTORY}

\section{An International Quarterly}

Editorial Committee: L. A. Fallers, G. E. von Grunebaum, Everett C. Hughes, Edward A. Kracke, Jr., Max Rheinstein, Edward Shils, Eric R. Wolf, Sylvia L. Thrupp (Editor)

Contents of Vol. IV, No. 4 (June 1962):

Vladimir C. Nahirny

The Russian Intelligentsia: from Men of Ideas to Men of Convictions

Joseph R. Levenson

Confucian and Taiping "Heaven": the Political Implications of Clashing Religious Concepts

Robert M. Marsh

The Venality of Provincial Office in China and in Comparative Perspective

George A. Floris

A Note on Dacoits in India

Richard M. Morse

Latin American Cities: Aspects of Function and Structure

René Millon, Clara Hall Conflict in the Modern Teotihuacan and May Diaz Irrigation System

J. G. A. Pocock

“History and Theory" (Review Article)

Subscription $\$ 6.00$ (U.S.A.) per year, or the equivalent in other currencies, payable through booksellers or directly to the publisher: Mouton and Company, The Hague, The Netherlands.

Supplement No. 1: Edward Shils, The Intellectual Between Tradition and Modernity: the Indian Situation, is now similarly obtainable. Price $\$ 3.00$ or, to subscribers, $\$ 2.00$. 


\section{BR I T A I N \\ AND CHINA}

\section{EVAN LUARD}

The central portion of $\mathrm{Mr}$. Luard's book deals with the decade since the recognition of the People's Republic-and with the fortunes of merchants and missionaries as well as with diplomacy, the Korean War, Formosa, and Hong Kong. It is preceded by a brilliant survey of relations between Britain and China in the last hundred years, and the book ends with a closely argued look at the future.

25s. net.

\section{Available from all good bookshops}

\section{CHATTO \& WINDUS}

\section{THE CHINA BULLETIN}

This new monthly bulletin of analysis seeks to provide a continuing record of important developments in China in the fields of politics, agriculture, industry, foreign relations and culture.

Though the Bulletin is primarily intended for the use of journalists, we think it will also be found valuable by scholars, politicians and diplomats and indeed anyone who feels, as we do, that it is essential to know what is happening in Communist China.

Subscriptions $£ 5$ per year

(including postage)

Published by

THE CHINA QUARTERLY

\section{LIBRARY OF INTERNATIONAL STUDIES}

\section{VOLUME 1

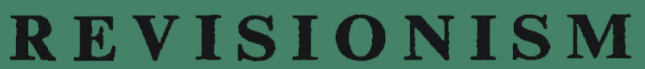

\section{ESSAYS ON THE HISTORY OF MARXIST IDEAS Edited by LEOPOLD LABEDZ}

This is the first volume to be published in the new Library of International Studies.

The book deals with the history of ideas associated with Marxist movements. These ideas, which so agitated the young Communist revisionists, are traced and analysed against their historical and contemporary background. Theoreticians who played the most important role in re-examining or modifying their assumptions are re-assessed from the perspective of the second balf of the twentieth century, among them Eduard Bernstein and Rosa Luxemburg, Leon Trotsky and Nikolai Bukharin, Geork Lukacs and Ernst Bloch. The significance of revisionism, its prospects inside the Communist bloc, and its impact on the 'New Left" outside it, are analysed by scholars of international repute. each dealing with his special subject.

The symposium also provides material on the Soviet attitude to revisionism and gives the necessary background for the understanding of the evolution of Communist ideology.

Demy 8 vo. 408 pases. 37s. 6d. net

Lomdon: George Allen \& Unwn Ltd. New York: Frederick A. Praeger Inc. 